E-ISSN : 2549-6581

DOI: 10.21776/ub.JOIM.2021.005.02.4

Artikel Hasil Penelitian

Diterima : 14 April 2020

Direview : 7 Juli 2021

Dimuat : Agustus - November 2021
OPEN ACCESS

Journal of Issues in Midwifer

\title{
Kepatuhan Ibu Nifas Dalam Pemanfaatan Buku KIA Terhadap Pencegahan Komplikasi Masa Nifas Di Kota Tarakan
}

\author{
Nur Indah Noviyanti ${ }^{\left.{ }^{*}\right)}$, Gusriani ${ }^{2}$ \\ 1*) Universitas Borneo Tarakan, nurindah@borneo.ac.id, 08114442011, Fakultas Ilmu Kesehatan, \\ Jurusan Kebidanan, Universitas Borneo Tarakan \\ 2 Universitas Borneo Tarakan, gusriani@borneo.ac.id, 082188737351, Fakultas IImu Kesehatan, \\ Jurusan Kebidanan, Universitas Borneo Tarakan
}

\begin{abstract}
Indonesia is currently still experienced problems related to the high maternal mortality rate (MMR) and infant mortality rate (IMR). So that the government makes efforts to reduce MMR and IMR. In this effort, in 1994 the government issued the $\mathrm{MCH}$ booklet, which is one of the strategies in reducing maternal and infant mortality rates, this strategy involves empowering the community, especially families and communities. In order to ensure the use of the $\mathrm{MCH}$ handbook in the community, the implementation of the $\mathrm{MCH}$ handbook is coordinated directly by the respective regional health offices. During the pandemic postpartum mothers find it difficult to access health facilities because of the right to service.

Therefore, to increase mother's knowledge, both about early detection of complications, health education, health promotion, it is hoped that mothers can support them through the KIA book that every pregnant and postpartum mother has. This study aims to determine the relationship between postpartum mother's adherence to the use of $\mathrm{MCH}$ book as an education to prevent complications in the Pandemic Era in the Sebengkok Community Health Center. This type of research used analytical research with cross sectional design. The population in this study were all postpartum mothers who were in the working area of the pusksemas Sebengkok from January to June 2020. The sampling technique in this study was purposive sampling. Based on the chi square test, the value of $\rho=0.011$ was obtained, which shows $\rho<\alpha(0.05)$, which means that there is a relationship between postpartum mothers' knowledge of the use of the $\mathrm{MCH}$ book during the COVID-19 pandemic.
\end{abstract}

Keywords : Obedience; Utilization; Post Partum; Book; Mother and Child Book

\section{ABSTRAK}

Di Indonesia saat ini masih mengalami masalah terkait tingginya angka kematian ibu (AKI) dan angka kematian bayi (AKB). Sehingga pemerintah melakukan usaha-usaha dalam penurunan AKI dan AKB. Dalam upaya tersebut tahun 1994 pemerintah mengeluarkan buku KIA yang merupakan salah satu strategi dalam penurunanan angka 
kematian ibu dan bayi, strategi ini melibatkan pemberdayaan masyarakat khususnya keluarga dan masyarakat. Agar menjamin penggunaan buku KIA di masyarakat maka penerapan buku KIA ini dikoordinasikan langsung oleh dinas kesehatan daerah masingmasing. Pada masa pandemi, ibu nifas sulit dalam mengakses layanan fasilitas kesehatan diakibatkan adanya pembatasan layanan.

Oleh karena itu untuk meningkatkan pengetahuan ibu baik tentang deteksi dini komplikasi, edukasi kesehatan, promosi kesehatan diharapkan didapatkan melalui buku KIA yang setiap ibu hamil dan ibu nifas miliki. Penelitian ini bertujuan untuk mengetahui hubungan kepatuhan ibu nifas terhadap pemanfaatan buku nifas sebagai sarana edukasi untuk pencegahan komplikasi di Era Pandemi di Wilayah Kerja Puskesmas Sebengkok. Jenis penelitian yang digunakan penelitian analitik dengan desain cross sectional. Populasi dalam penelitian ini adalah seluruh lbu nifas yang berada diwilayah kerja Puskesmas Sebengkok dari bulan Januari sampai Juni 2020. Teknik pengambilan sampel dalam penelitian ini adalah purposive sampling. Berdasarkan uji chi square diperoleh nilai $\rho=0,011$ yang menunjukan $\rho<\alpha(0,05)$ artinya ada hubungan antara pengetahuan ibu nifas tentang pemanfataan buku KIA selama masa pandemi COVID-19.

Kata kunci : Kepatuhan; Pemanfaatan; Nifas: Buku; KIA

*Korespondensi: Nur Indah Noviyanti. Surel: nurindah@borneo.ac.id

\section{PENDAHULUAN}

Angka kematian ibu yang masih cukup tinggi di Indonesia menjadi problematika yang cukup besar. Data yang ditampilkan Survei Demografi Kesehatan Indonesia (SDKI) tahun 2012 yaitu 359 per 1000.000 kelahiran hidup, angka ini menunjukan bahwa tugas Indonesia untuk mencapai Sustainable Develompemnt Goals (SDG'S) masih jauh dari harapan. Penyebab dari kematian ibu di Indonesia tertinggi diakibatkan dari beberapa faktor langsung yang berhubungan dengan komplikasi pada masa kehamilan, persalinan, dan nifas. Kematian maternal di Indonesia selama masa pandemi memberikan atensi yang cukup besar terhadap AKI di Indonesia, data dari Dinas Kesehatan Kabupaten Tegal Angka kematian ibu hamil dan melahirkan selama masa pandemi dari bulan Januari sampai Juni 2020 mencapai 14 kasus. Hal ini berbeda pada tahun 2019, kasus kematian maternal ada 12 kasus. Pada tahun 2013 kematian ibu karena

perdarahan yaitu $30,1 \%$, selanjutnya hipertensi $27,1 \%$, infeksi 7,3 \%, partus lama 1,8\% , abortus 1,6\% dan penyebab lainnya 40,8\% (1). Kalimantan sebagai Provinsi termuda di Indonesia melaporkan jumlah Kematian Ibu pada triwulan I tahun 2019 sebanyak 4 kasus AKI, sedangkan di kota Tarakan terdapat 6 kasus AKI pada tahun 2018. Selain faktor langsung adapula faktor yang tidak langsung yaitu dimana ibu hamil terlalu muda, terlalu tua, paritas, dan multipara (2).

Tahun 1994 pemerintah meluncurkan buku Kesehatan Ibu dan Anak yang penggunaannya saat ini telah digunakan seluruh Provinsi di Indonesia. Buku KIA merupakan salah satu strategi dalam penurunan angka kematian ibu dan bayi, strategi ini melibatkan pemberdayaan 
khususnya keluarga dan masyarakat. Agar menjamin penggunaan buku KIA di masyarakat maka penerapan buku $\mathrm{KIA}$ ini dikoordinasikan langsung oleh dinas kesehatan daerah masing-masing. Buku KIA merupakan media yang digunakan tenaga kesehatan untuk mendeteksi komplikasi atau resiko secara dini atau adanya masalah kesehatan yang dialami ibu dan anak, selain itu buku KIA menjadi alat komunikasi serta alat penyuluhan dengan berbagi informasi penting bagi ibu, keluarga dan masyarakat, yang terdiri dari pelayanan KIA, gizi, imunisasi, dan pertumbuhan serta perkembangan balita.

Buku KIA dimanfaatkan sebagai media Konseling Informasi Edukatif (KIE) yang sangat mudah tersampaikan pesan-pesan terkait kesehatan ibu, anak dan keluarga karena buku ini dikemas secara menarik dengan adanya gambargambar yang mempermudah ibu dan keluarga untuk memahami isi buku tersebut. Selain itu buku KIA sebagai alat pendokumentasian atau bukti pencatatan pelayanan kesehatan yang telah diberikan Bidan atau tenaga kesehatan secara menyeluruh dan berkesinambungan (3). Dimasa pandemi COVID-19 Pelayanan Kunjungan lbu nifas di tunda untuk datang ke fasilitas kesehatan apabila tidak mengalami tanda bahaya dalam kegawatdaruratan. Namun agar pelayanan kebutuhan ibu nifas dan bayi dapat optimal maka petugas kesehatan melakukan kunjungan rumah sesuai prosedur yang telah dikeluarkan oleh Kementerian Kesehatan. Pandemi COVID-19 menyebabkan begitu besar masalah dalam pemberian pelayanan kesehatan, khususnya pelayanan kesehatan ibu dan anak. Hal ini karena adanya penundaan kunjungan/ konsultasi dan pemeriksaan maternal dan neonatal ke fasilitas kesehatan bila ibu dan anak tidak mengalami gejala, tanda bahaya, atau kegawatdaruratan maternal. Hal ini dikarenakan adanya kehawatiran adanya penularan COVID-19 yang dapat terjadi, sehingga ibu disarankan untuk tetap dirumah saja, dan dianjurkan membaca buku KIA dan menjaga kondisi kesehatannya. Dampak dari pandemi dalam pelayanan kesehatan adalah tidak optimalnya pelayanan kesehatan yang diberikan kepada ibu dan anak sehingga hal ini nantinya dapat menimbulkan resiko meningkatnya AKI dan AKB (4).

$\begin{array}{ccc}\text { Menurut data dari Dinas } \\ \text { Kesehatan } & \text { Kota }\end{array}$
didapatkan bahwa kunjungan nifas di kota Tarakan sebesar $85,1 \%$, Berdasarkan data dari Puskesmas Sebengkok kota Tarakan jumlah kunjungan nifas pada bulan Januari sampai Maret 2020 sebanyak 157 bu nifas $(17,1 \%)$. Penurunan jumlah presentasi dari kunjungan nifas disebabkan adanya pembatasan aktifitas pelayanan kesehatan untuk mencegah penyebaran COVID-19, serta adanya kekhawatiran Ibu nifas untuk datang ke layanan kesehatan selama masa pandemi. Adanya masalah-masalah terkait pencegahan penyebaran virus COVID-19, sehingga Bidan dan petugas kesehatan menganjurkan lbu nifas jika tidak memiliki keluhan untuk menahan dalam melakukan kunjungan nifas. Sebuah penelitian mengungkapkan bahwa $57,1 \%$ buku KIA memiliki fungsi komunikasi yang baik dalam memberikan edukasi, serta $61,5 \%$ buku KIA dapat menjadi 
sumber pengetahuan untuk ibu. Berdasarkan uraian data di atas, maka peneliti mengadakan penelitian tersebut untuk mengetahui hubungan kepatuhan ibu nifas dalam pemanfaatan buku KIA terhadap pencegahan komplikasi masa nifas di Puskesmas Sebengkok Kota Tarakan.

\section{METODE PENELITIAN}

\section{Rancangan/Desain Penelitian}

Jenis penelitian ini menggunakan penelitian analitik dengan desain cross sectional. Penelitian ini untuk mengetahui hubungan kepatuhan ibu nifas dalam pemanfaatan buku KIA terhadap pencegahan komplikasi nifas pada masa pandemi di Puskesmas Sebengkok Kota Tarakan.

\section{Sumber Data}

Sumber data yang diperoleh dalam penelitian ini berjumlah dua data, yaitu data sekunder yang didapatkan dari Puskesmas Sebengkok kota Tarakan di tahun 2020 dan data kedua yaitu data primer berupa kuesioner diisi oleh responden melalui google form.

\section{Sasaran Penelitian (Populasi/Sampel/Subjek Penelitian)}

Populasi dalam penelitian ini adalah seluruh lbu nifas yang berada di wilayah kerja Pusksemas Sebengkok Kota Tarakan dari bulan Januari sampai Juni 2020. Teknik pengambilan sampel dalam penelitian ini adalah purposive sampling, dimana besar sampel dalam penelitian berjumlah 30 ibu nifas, diambil pada bulan Mei-Juni 2020 sesuai kriteria inklusi dan eksklusi. Penelitian ini dilaksanakan di Wilayah kerja Puskesmas Sebengkok.

\section{Pengembangan Instrumen dan Teknik Pengumpulan Data}

Instrumen pertama dalam penelitian ini adalah kuesioner yang berisi beberapa pertanyaan yang terkait dengan data karakteristik responden dan instrumen kedua adalah kuesioner persepsi ibu nifas terhadap buku KIA. Instrumen ketiga adalah pemanfataan buku KIA sebagai media edukasi pencegahan komplikasi masa nifas dan instrument keempat adalah kuesioner komplikasi/ kegawatdaruratan yang diadop dari Panduan Pelayanan Pasca Persalinan Bagi Ibu Dan Bayi, yang dikeluarkan oleh Kementerian Kesehatan Republik Indonesia tahun 2020.

\section{Teknik Analisis Data}

Analisis dalam penelitian ini menggunakan uji statistik chi Square. Analisis data dilakukan dengan pengelolaan data dengan bantuan computer program excel dan SPSS versi 21

\section{HASIL PENELITIAN}

Responden yang diperoleh dari pengumpulan data lbu nifas di Puskesmas Sebengkok dilihat berdasarkan usia Pendidikan, pekerjaan, kunjungan nifas, motivasi bidan, pendamping membaca buku KIA responden pada tabel dibawah ini. 
Tabel 1. Distribusi Karakteristik Responden Berdasarkan Usia Pendidikan, Pekerjaan, Kunjungan Nifas, Motivasi Bidan, Pendamping Membaca Buku

\begin{tabular}{|c|c|c|c|}
\hline \multicolumn{2}{|c|}{ Karakteristik Responden } & \multirow{2}{*}{$\begin{array}{c}\text { Jumlah } \\
5\end{array}$} & \multirow{2}{*}{$\begin{array}{c}\text { Presentase } \\
16,6 \%\end{array}$} \\
\hline Usia ibu & $<20$ tahun & & \\
\hline & 20-35 tahun & 19 & $63,3 \%$ \\
\hline & $>35$ tahun & 6 & $20 \%$ \\
\hline Total & & 30 & $100 \%$ \\
\hline \multirow[t]{3}{*}{ Pendidikan } & $\begin{array}{c}\text { Perguruan } \\
\text { Tinggi }\end{array}$ & 12 & $40 \%$ \\
\hline & SMA & 15 & $50 \%$ \\
\hline & SMP & 3 & $10 \%$ \\
\hline Total & & 30 & $100 \%$ \\
\hline \multirow[t]{2}{*}{ Pekerjaan } & Bekerja & 15 & $50 \%$ \\
\hline & Tidak Bekerja & 15 & $50 \%$ \\
\hline Total & & 30 & $100 \%$ \\
\hline Kunjungan nifas & $\mathrm{Ya}$ & 19 & $63,3 \%$ \\
\hline Selama COVID-19 & Tidak & 11 & $36,7 \%$ \\
\hline Total & & 30 & $100 \%$ \\
\hline \multirow[t]{2}{*}{ Motivasi Bidan } & $\mathrm{Ya}$ & 30 & $100 \%$ \\
\hline & Tidak & 0 & 0 \\
\hline Total & & 30 & \\
\hline \multirow[t]{2}{*}{ Membaca Buku KIA } & $\mathrm{Ya}$ & 18 & $60 \%$ \\
\hline & Tidak & 12 & $40 \%$ \\
\hline Total & & 30 & $100 \%$ \\
\hline Pendamping membaca & Sendiri & 23 & $76,6 \%$ \\
\hline \multirow[t]{2}{*}{ Buku KIA } & Suami & 7 & $23,4 \%$ \\
\hline & Keluarga & 0 & 0 \\
\hline Total & & 30 & $100 \%$ \\
\hline
\end{tabular}

*Uji Chi Square

Tabel 1 menunjukkan bahwa dari 30 responden sebanyak 5 $(16,6 \%)$ responden berumur kurang dari 20 tahun, sebanyak $19(63,3 \%)$ responden berumur 20 tahun sampai dengan 35 tahun dan sebanyak $6 \quad(20 \%)$ responden berusia lebih dari 35 tahun. Berdasarkan kategori Pendidikan, sebanyak $12(66,2 \%)$ responden dengan pendidikan terakhir perguruan tinggi, sebanyak 15 $(50 \%)$ responden dengan pendidikan terakhir SMA, sebanyak $3 \quad(10 \%)$ responden dengan pendidikan terakhir SMP.

Kategori pekerjaan menunjukkan dari 30 responden sebanyak $15(50 \%)$ dengan status bekerja dan 15 responden (50\%) dengan status tidak bekerja. Kategori ibu nifas yang telah melakukan kunjungan nifas selama masa COVID-19 dari 30 responden terdapat $19(63,3 \%)$ ibu nifas yang telah mengunjungi fasilitas 
Kesehatan dan sebanyak 11 $(36.7 \%)$ belum melakukan kunjungan nifas. Kategori bidan melakukan motivasi dan konseling melalui media sosial whatsapp messenger sebanyak 30 orang $(100 \%)$ ibu nifas telah dimotivasi oleh bidan. Kategori ibu nifas yang membaca buku KIA, dari 30 responden sebanyak $18(60 \%)$ yang membaca buku KIA, dan 12 (40\%) tidak membaca buku KIA setiap hari. Sedangkan untuk kategori pendamping ibu nifas dalam membaca buku KIA dari 30 responden sebanyak $23(76,6 \%)$ ibu nifas membaca buku KIA sendiri dan $7(23,4 \%)$ ibu nifas membaca buku KIA dengan suami, sedangkan $0(0 \%)$ atau tidak ada ibu nifas yang bersama keluaraga membaca buku $\mathrm{KIA}$.

Tabel 2. Distribusi Sikap lbu Nifas Tentang Pemanfaatan Buku KIA Di Puskesmas Sebengkok Kota Tarakan.

\begin{tabular}{ccc}
\hline Pengetahuan & Jumlah & Presentasi \\
\hline Positif & 19 & $63,3 \%$ \\
Negatif & 11 & $36,6 \%$ \\
Total & 30 & $100 \%$ \\
\hline
\end{tabular}

Tabel 3. Distribusi Pengetahuan Ibu Nifas Tentang Pemanfaatan Buku KIA Di Puskesmas Sebengkok Kota Tarakan

\begin{tabular}{ccc}
\hline Pengetahuan & Jumlah & Presentasi \\
\hline Baik & 12 & $40 \%$ \\
Cukup & 14 & $46,6 \%$ \\
Kurang & 4 & $13,4 \%$ \\
Total & 30 & $100 \%$
\end{tabular}

$30 \begin{array}{cc}\text { Pada tabel } 2 & \text { menunjukan dari } \\ \text { responden sebanyak } 19\end{array}$ responden $(63,3 \%)$ memiliki persepsi yang positif tentang pemanfaatan buku KIA. Pada tabel 3 menunjukan sebanyak 12 responden (40\%) memiliki pengetahuan yang baik tentang pemanfaatan buku KIA, sebanyak $14(46,6 \%)$ responden memiliki pengetahuan yang cukup dan sebanyak $4 \quad(13,4 \%)$ responden memiliki pengetahuan yang kurang tentang pemanfaatan buku KIA.

Tabel 4 menunjukan bahwa dari 30 respoden, tercatat 15 responden memiliki pengetahuan baik dengan sikap yang positif 12 responden sedangkan 3 responden yang memiliki pengetahuan baik namun memiliki sikap negatif dalam pemanfaatan buku KIA. Terlihat pula dari 10 responden dengan pengetahuan cukup, tercatat 9 responden memiliki sikap positif dan 1 satu responden memilikisifat negatif. Kategori terakhir yaitu pengetahuan kurang sebanyak 5 responden dengan sikap positif 1 responden dan 8 orang responden memiliki sikap negatif. Berdasarkan uji chi square diperoleh nilai $\rho=$ 0,011 yang menunjukan $\rho<\alpha(0,05)$ artinya ada hubungan antara pengetahuan ibu nifas tentang 
pemanfataan buku KIA selama masa pandemi COVID-19.

Tabel 4. Hubungan Sikap Ibu Nifas Dan Pengetahuan Ibu Nifas Tentang Pemanfaatan Buku KIA di Puskesmas Sebengkok Kota Tarakan

Pengetahuan Pemanfaatan Buku KIA

\begin{tabular}{cccccc} 
& Positif & $\%$ & Negatif & $\%$ & Total \\
\hline Baik & 12 & $80 \%$ & 3 & $30,76 \%$ & 15 \\
Cukup & 9 & $90 \%$ & 1 & $69,23 \%$ & 10 \\
Kurang & 1 & $20 \%$ & 4 & $0 \%$ & 5 \\
Total & 22 & $100 \%$ & 8 & $100 \%$ & 30 \\
\hline
\end{tabular}

*Uji Chi Square

\section{PEMBAHASAN}

Hasil penelitian yang dilakukan terlihat bahwa umur dan pendidikan responden akan menjadi salah satu faktor tingkat pengetahuan dan kematangan seseorang dalam bersikap dan mengambil keputusan. Umur dibawah 20 tahun pada ibu dan tingkat pendidikan yang cukup rendah menjadi masalah yang terjadi tidak hanya di daerah Tarakan namun juga terjadi di beberapa daerah Kabupaten lainya seperti daerah Kabupaten Lamongan. Hal ini menjadikan tingkat pengetahuan ibu nifas rendah terhadap pengetahuan kesehatan ibu khususnya terkait tanda bahaya dalam masa nifas (5). Melihat hal ini, tentunya peran dari tenaga kesehatan dan masyarakat sangat diperlukan dalam meningkatkan pengetahuan dan sikap positif responden/ ibu nifas agar angka kesakitan ibu dan anak dapat diturunkan.

Kunjungan nifas yang merupakan bagian terpenting dalam pemantauan kesehatan ibu dan anak dan pencegahan komplikasi diharapkan menjadi sebuah kesadaran setiap ibu dan keluarga (6). Kunjungan nifas tidak hanya berupa pemeriksaan Kesehatan ibu dan bayi, namun juga ibu diberikan edukasi untuk meningkatkan derajat kesehatannya. Dalam masa pandemi COVID-19 terjadi pembatasan pelayanan fasilitas kesehatan, sehingga diharapkan ibu nifas dan keluarga dapat memberdayakan peran alat Kesehatan seperti buku KIA untuk mendapatkan berbagai macam informasi terkait Kesehatan ibu dan bayi. Kunjungan nifas yang masih berjalan dalam masa pandemi tetap dilakukan di Puskesmas Sebengkok dengan tetap melaksanakan protokol kesehatan dan melakukan janji ketemu dengan bidan mereka. lbu nifas yang melakukan janji ketemu dalam pelayanan masa nifas sebanyak 9 orang $(60 \%)$. Selama masa nifas terjadi perubahan secara fisologi dan psikologi sehingga hal ini membuat ibu menjadi tidak nyaman dan bahkan terganggu. Namun dengan adanya pelayanan kunjungan nifas hal ini dapat teratasi karena informasi dan edukasi yang diberikan bidan sesuai dengan kebutuhan ibu nifas (7).

Pemanfataan buku KIA sebagai media informasi Kesehatan Ibu dan Anak, pemantauan kesehatan serta tumbuh kembang 
anak menjadi hal yang sangat penting. Edukasi buku KIA yang baik oleh tenaga kesehatan dimulai dari kehamilan hingga nifas memberikan sikap yang positif kepada responden di Puskesmas Sebengkok yaitu 19 responden $(63,3 \%)$. Penelitian yang dilakukan di Puskesmas Ajibarang menjabarkan bahwa terdapat hubungan pencatatan buku KIA dengan pengetahuan $K I A$, namun hal lain menunjukan pada penelitian yang dilakukan tidak ada hubungan antara edukasi dan komunikasi buku KIA dengan pengetahuan buku KIA. Hal ini dapat saja terjadi karena ibu yang memiliki buku KIA hanya membawa buku dilayanan Kesehatan untuk diisi oleh petugas posyandu dan tidak ada feedback antara keduanya, sehingga intervensi yang ada pada buku KIA tidak diimplementasikan (8). Sebuah penelitian yang dilakukan di Palestina, Burundi dan Mongolia, memperlihatkan bahwa di negara Palestina buku KIA telah dibuat dengan penuh ilustrasi menarik dan bahasa yang lebih mudah dipahami dalam Bahasa Arab, sedangkan untuk negara Burundhi (South Africa) buku KIA mempunyai fungsi sebagai pencatatan kehamilan, persalinan, nifas, vaksin, tumbuh kembang anak dan kunjungan klinik. Selain itu buku KIA mempunyai fungsi untuk informasi dan kesadaran terhadap pentingnya Kesehatan Ibu dan Anak, serta meningkatkan pelayanan dasar. Pentingnya buku KIA sebagai sarana pendidikan kesehatan bagi ibu dan anak dapat menjadi acuan ibu dimulai dari kehamilannya, pemantauan tumbuh kembang anak hingga usia 5 tahun, menjadi pengantar media komunikasi informasi ibu, bidan dan keluarga (9).

Penelitian

ini menggungkapkan bahwa pemanfaatan buku KIA yang positif akan memberikan dampak terhadap peningkatan pengetahuan yang baik hal ini pengaruhi oleh perilaku manusia yang dapat berasal dari pengalaman dan interaksi manusia sehingga terwujud pengetahuan dan sikap yang baik. Pada penelitian ini terlihat bahwa dari 30 ibu terdapat 12 responden (80\%) yang memanfaatkan buku KIA yang positif dengan pengetahuan yang baik. Pemanfataan buku KIA yang dilakukan ibu nifas dapat terlihat dari kemampuan mengetahui edukasi terkait derajat kesehatan ibu dan perkembangan bayi, pengisian buku KIA dan juga dapat terlihat saat ibu aktif membawa buku KIA dalam mendapatkan pelayanan ibu dan anak (8). Selama masa pandemi COVID-19 buku KIA menjadi pendamping ibu nifas dalam mendapatkan banyak informasi terkait Kesehatan lbu dan Anak. Intervensi ini dilakukan dengan harapan mengurangi kontak human to human di fasilitas Kesehatan.

Pemanfaatan buku KIA dilakukan oleh ibu dimulai dari mereka melakukan kunjungan antenatal pertama kali. Mulai saat Bidan telah memberikan media edukasi dan informasi serta komunikasi terkait Kesehatan. Sehingga pada saat masa nifas ibu telah mendapatkan banyak pengetahuan terkait Kesehatan diri dan bayinya. Penelitian yang dilakukan pada Puskesmas Pekalongan menunjukan peran bidan dalam mendukung ibu memanfaatkan buku KIA terlihat dari pencatatan buku KIA setiap selesai 
melakukan pemeriksaan, dan melakukan diskusi dengan ibu. Hal tersebut membuat ibu menjadi termotivasi dalam pemanfaatan buku KIA yang tidak hanya berguna untuk bidan sebagai pendokumentasian tetapi menjadi kebutuhan ibu dalam mendapatkan edukasi untuk dirinya dan bayinya (10).

\section{SIMPULAN}

Pemanfataan buku KIA selama masa pandemi COVID-19 mempunyai peran penting dalam mengurangi kontak manusia atau pembatasan sosial atau jarak. Pemanfataan buku KIA sangat penting untuk dilakukan dikarenakan presentasi umur pada masa nifas < 20 tahun masih cukup tinggi, ratarata tingkatan Pendidikan pada responden pada penelitian ini menunjukan bahwa Pendidikan yang tertinggi pada ibu nifas didaerah wilayah kerja Puskesmas Sebengkok adalah ibu tamatan SMA. Buku KIA merupakan media yang sangat penting dalam memberikan informasi dan komunikasi antara tenaga Kesehatan dan ibu. Pada masa pandemi COVID-19 dimana terjadi pembatasan layanan kesehatan, mengakibatkan ibu nifas tidak mendapatkan layananan edukatif dan pencegahan serta pemeriksaan dari bidan atau petugas kesehatan. Hanya ibu nifas yang mengalami keluhan yang dapat ke pelayanan kesehatan dengan melakukan janji temu dengan bidan terlebih dahulu.

Selama masa pandemi COVID-19, Ibu nifas di wilayah kerja Puskesmas Sebengkok telah menjadikan buku KIA menjadi sarana edukasi dan informasi untuk Ibu dan keluarga, hal ini terlihat dari persepsi positif dari responden ibu nifas dalam membaca dan keluarga yang mendampingi lbu membaca buku KIA serta bidan yang memotivasi ibu dalam memanfaatkan buku KIA. Terjadi peningkatan pengetahuan positif pada ibu nifas selama memanfaatkan buku KIA. Hal ini juga berhubungan terhadap sikap positif ibu nifas dalam pemnafaatan buku KIA di Puskesmas Sebengkok Kota Tarakan.

\section{DAFTAR PUSTAKA}

1. Cherry K. Mother's day. Vol. 33, Kenyon Review. 2011. p. 4-19.

2. Afifah T, Tejayanti T, Saptarini I, Rizkianti A, Usman $Y$, Senewe FP, et al. Maternal Death In Indonesia: Follow-Up Study Of The 2010 Indonesia Population Census. J Kesehatan Reproduksi. 2016;

3. Kementrian Kesehatan RI. Petunjuk teknis penggunaan buku KIA. Kementrian Kesehatan RI. 2015;1-48.

4. RI KK. Pedoman Bagi Ibu Hamil, Ibu Nifas, dan Bayi Baru Lahir selama Social Distancing. 2020;

5. Muthoharoh H. Studi Pengetahuan lbu Nifas Tentang Tanda Bahaya Selama Masa Nifas (Di Desa Pomahan Janggan, Kecamatan Turi, Kabupaten Lamongan 2015). Kebidanan. 2016;

6. Achyar K, Rofiqoh I. Pengaruh Kunjungan Nifas terhadap Komplikasi Masa Nifas di 
Wilayah Puskesmas Sokaraja 1 Kabupaten Banyumas. J IIm Ilmu-ilmu Kesehatan. 2016;

7. Nuryati S, Yanti RD. Efektifitas Penggunaan Media Sosial Terhadap Peningkatan Pengetahuan Perawatan Nifas Dan Kepatuhan Kunjungan Ulang Pada lbu Nifas Di Kota Bogor. J Bidan "Midwife J. 2017;

8. Sistiarani C, Gamelia E, Sari DUP. Fungsi Pemanfaatan Buku KIA terhadap Pengetahuan Kesehatan lbu dan Anak pada Ibu Function of Utilization Maternal Child Health Book to Maternal Knowledge. J Kesehat Masy Nas. 2014;

9. Wike Pratiastuti AS. Evaluation of Mother and Child Health (Mch) Handbook: A Systematic Review. Proc Int Conf Appl Sci Heal. 2018;3.

10. Khuzaiyah S, Khanifah M, Chabibah N. Evaluasi Pencatatan \& Pemanfaatan Buku Kesehatan Ibu dan Anak (KIA) Oleh Bidan, Ibu dan Keluarga. Indones J Nurs Pract. 2018; 